\title{
Analysis of the causes of abnormal quality of gypsum wet FGD system \\ and suggestions
}

\author{
Xueying Zhang ${ }^{1, \text { a }}$,Shuo Yang ${ }^{1, b}$,Ruifeng Dong ${ }^{1, c}$ \\ 1Electric Power Research Institute of Henan Electric Power Company, Zhengzhou P.R.China \\ a hnzhangxueying@163.com, b yangshuozi@126.com ,c drfcom2005@163.com
}

Keywords:Wet desulfurization;gypsum; abnormal analysis ; proposal

\begin{abstract}
For the maintenance of a 330 MW limestone - gypsum wet flue gas desulfurization system found, in-depth analysis of the factors affecting the desulfurization gypsum quality, including: impurities in gypsum, absorption tower impurity balance, desulfurization absorbent quality, lime stone particle size. And attention in the operation of the desulfurization system and suggestions.
\end{abstract}

\section{Introduction}

Thermal power plant of limestone - gypsum wet flue gas desulfurization (FGD) due to technical maturity, high desulfurization efficiency, stable operation and other advantages has been widely used. But in the desulfurization system daily operation process, often abnormal quality of gypsum desulfurization system, serious of desulfurization system steady operation cause security risks. The desulfurization system for 330MW subcritical coal-fired power generating units overhaul period found problems, for example, the existence of the cause of the problem of analysis and put forward the measures to solve the problem.

\section{The desulfurization system problems}

Wet FGD system in the power plant officially put into operation in 2011 , a furnace a tower, all the amount of flue gas desulfurization system processing, limestone slurry system, gypsum dewatering system for two sets of desulfurization equipment utilities. Recently, during the desulfurization system overhaul found at the bottom of the absorption tower desulfurization absorption sediment anomalies. The impurity content is high in the tower bottom sediments, the phenomenon of clogging problems slurry circulating pump strainer. Sediment dewatering drying is divided into two layers. The upper layer material for gypsum, gypsum Bakai, lower the emergence of a large number of black granular material, significantly different from the upper material; now concurrent slurry circulating pump entrance filter attached with a hard scale, it is very difficult to remove. This black substance in the absorption tower at the bottom of a large number of deposition. Effect of gypsum comprehensive quality, and cause on the desulfurization and stable operation of the system.

\section{Cause analysis}

\section{Gypsum sediment impurity content high absorption tower}

Of desulfurization unit to run record query showed that the $\mathrm{pH}$ value of the desulfurization unit, 
slurry density, inlet SO2 concentration, desulfurization efficiency and other parameters were within the normal range, the absorption tower slurry, gypsum, gypsum sediment sampling (Fig.1,2); samples in the 115 times magnification microscopy was employed to observe the gypsum and gypsum deposits images (as shown in Fig. 2, 3,4); the main constituents of the sample test results are shown in Table 1 below.

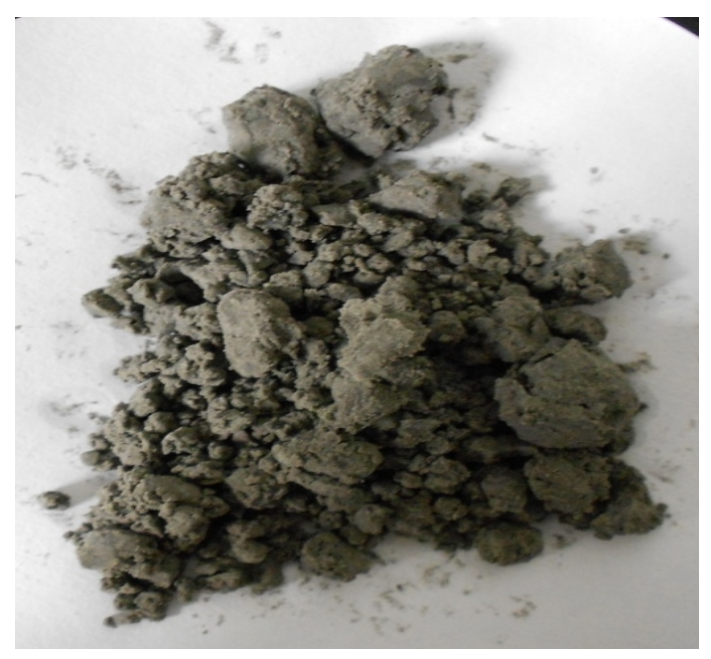

Fig. 1 gypsum sample

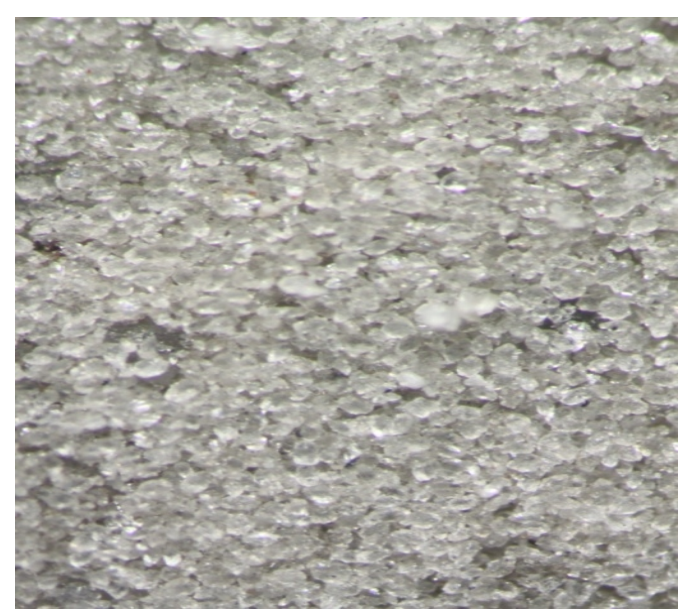

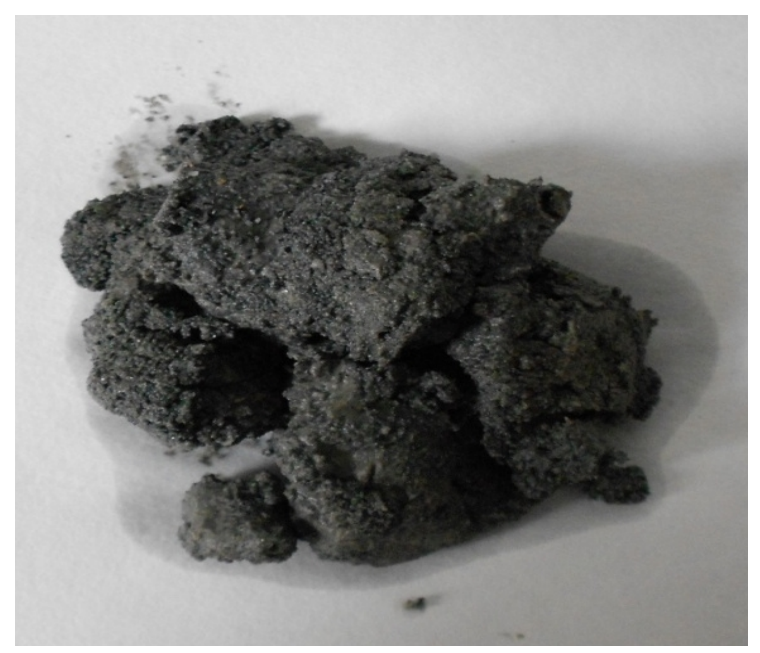

Fig. 2 gypsum sample

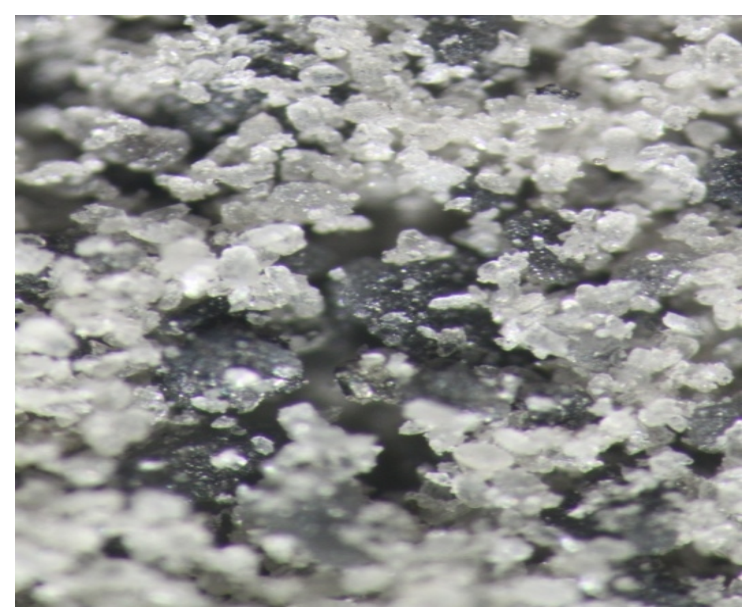

Fig. 3 microscope photographs of gypsum Fig. 4 microscope photographs of gypsum deposits

Table 1 Sample analysis results

\begin{tabular}{|c|c|c|c|c|c|c|}
\hline \multirow{2}{*}{ Test items } & $\mathrm{CaSO}_{4} \cdot 2 \mathrm{H}_{2} \mathrm{O}$ & $\mathrm{CaSO}_{3} \cdot 0.5 \mathrm{H}_{2} \mathrm{O}$ & $\mathrm{CaCO}_{3}$ & $\mathrm{SiO}_{2}$ & $\mathrm{Al}_{2} \mathrm{O}_{3}$ & $\mathrm{Fe}_{2} \mathrm{O}_{3}$ \\
\cline { 2 - 7 } & $\%$ & $\%$ & $\%$ & $\%$ & $\%$ & $\%$ \\
\hline design value & $>90$ & 0.32 & 8.94 & 3.41 & 1.13 & 0.36 \\
\hline $\begin{array}{c}\# 1 \text { absorption tower } \\
\text { Slurry }\end{array}$ & 82.50 & 0.32 & 13.59 & 4.28 & 2.01 & 0.50 \\
\hline $\begin{array}{c}\# 1 \text { absorption tower } \\
\text { Slurry }\end{array}$ & 75.08 & 0.52 & 50.57 & 4.56 & 1.98 & 0.92 \\
\hline $\begin{array}{c}\# 2 \text { absorption tower } \\
\text { of gypsum deposits }\end{array}$ & 34.06 & 0.24 & 9.77 & 4.54 & 1.70 & 0.48 \\
\hline $\begin{array}{c}\text { After dehydration of } \\
\text { gypsum }\end{array}$ & 80.11 & $\%$ & & $/$ & \\
\hline
\end{tabular}

From figure 3,4 can be seen, the gypsum in the sediments of caso $4-2 \mathrm{~h} 2 \mathrm{o}$ purity low impurity 
content is higher; from table 1 test results showed that the content of caso4-2h2o, $\mathrm{CaCO} 3$ content did not reach the design value; $\mathrm{SiO} 2, \mathrm{~A} 12 \mathrm{O} 3$ high content of impurities; gypsum sediment content of caso4-2h2o, $\mathrm{CaCO} 3$ containing volume two indicators are far higher than the design value.

\section{The internal balance of impurity absorption tower}

In order to ensure the stable operation of the desulfurization equipment must be assured, absorption tower of various material balance, including various solid impurities. Into the absorption tower of solid impurities, including: absorption tower sets of dust catching, limestone and the process water impurities; absorption tower to discharge impurities including: carry desulfurization wastewater emissions and gypsum; absorption tower system of impurity balance as shown in Figure 5:

The dust contained in

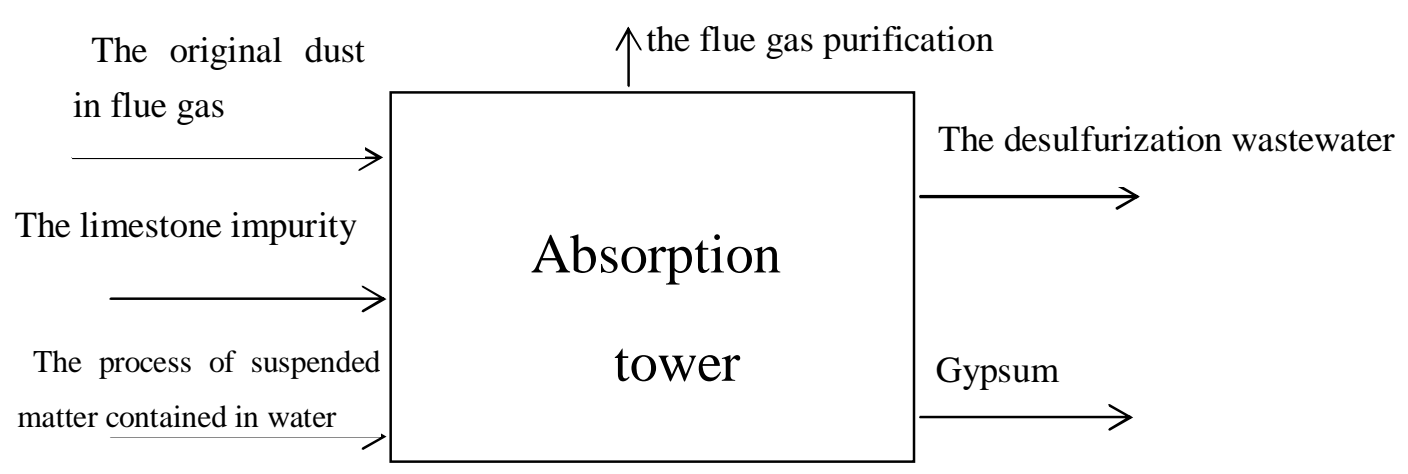

Fig.5 The internal equilibrium impurity absorption tower

Desulfurization device for continuous, stable operation, absorption tower should be substantially free of impurities deposition, through emissions desulfurization wastewater and removal of gypsum to maintain absorption tower of impurity balance. For desulfurization wastewater treatment system output Co., such as entering into the absorption tower of the impurity content of more (with high dust content and purity of the limestone low), gypsum impurities in the inevitable high, gypsum purity decline.

\section{Desulfurization absorbent quality}

The desulfurization system is ordinary absorbent limestone and stone (gravel) foam mixture, site of limestone, stone powder, limestone slurry sampling, analysis results are shown in table 2:

Table 2 Analysis of test results of sampling

\begin{tabular}{|c|c|c|c|c|c|}
\hline \multirow{2}{*}{ Test items } & $\mathrm{CaCO}_{3}$ & $\mathrm{MgCO}_{3}$ & $\mathrm{SiO}_{2}$ & $\mathrm{Al}_{2} \mathrm{O}_{3}$ & $\mathrm{Fe}_{2} \mathrm{O}_{3}$ \\
\cline { 2 - 6 } & $\%$ & $\%$ & $\%$ & $\%$ & $\%$ \\
\hline Limestone & 87.11 & 5.80 & 4.70 & 1.76 & 0.86 \\
\hline stone powder & 83.54 & 8.34 & 4.92 & 1.72 & 0.87 \\
\hline limestone slurry & 75.89 & 9.14 & 5.08 & 1.48 & 1.32 \\
\hline
\end{tabular}

The results showed that $\mathrm{CaCO} 3$ content is low; $\mathrm{MgCO} 3, \mathrm{SiO} 2, \mathrm{Al} 2 \mathrm{O} 3$ content is high; limestone $\mathrm{CaCO} 3$ content is low, higher content of other impurities. Limestone in the higher levels of 
impurities is bound to enter the absorption tower with relatively high content of impurities, gypsum purity decline, it is recommended strengthening the desulfurization of limestone quality supervision, of low purity limestone given to reject the.

\section{The size of limestone}

Fineness is an important parameter of the desulfurization performance of limestone. Under the same conditions of limestone powder is fine, the smaller particle size, larger specific surface area, and acid reaction speed faster, under the same conditions and soluble in water of the $\mathrm{SO} 2$ reaction more fully and absorption tower slurry and gypsum in the rest of the calcium carbonate content is low.

The results of limestone slurry sampling and assaying the fineness show that the fineness of limestone is less than $53 \mathrm{~m}$ (270 mesh) the proportion of the average value is $23.32 \%$; the fineness of limestone is less than $62 \mathrm{~m}$ (230 mesh) the proportion of the average value is $26.45 \%$.

\section{Conclusions and Suggestions}

(1) $\mathrm{CaCO} 3$ was the main component of sediment impurities, lime stone particle size too large is the main cause of the abnormal quality of gypsum; lime particle size is too large, poor chemical reaction activity reaction incomplete, almost deposited in at the bottom of the absorption tower, it is difficult to remove. Recommendations for enhancing the management and maintenance of the ball mill, periodically check the ball and wet mill liner wear, increase the number of balls and grinding depth.

(2) Desulfurization with limestone low purity, poor quality, high impurity content. Al2O3 $\mathrm{SiO} 2$, proposed to strengthen the quality control of limestone desulfurization, low purity limestone to be rejected.

(3) Absorption tower slurry collector sets of dust, limestone contains impurities is an important reason for the decrease in gypsum purity, it is recommended to control the coal ash, and operation optimization of the dust collector, and strengthen the supervision of limestone quality, reduce into the absorption tower of the impurity content.

(4) Strengthen the desulfurization wastewater treatment system operation and maintenance, to ensure the stability of the system of wastewater treatment, control of chloride concentration and solid impurities, fluorine plasma.

(5) Suggestions for the development of wet mill inspection, optimization of the project.

\section{References}

1. XX Zhou, XY Zhang, XF Dong. The Analysis and Operation Control for the Gypsum's Low Purity of Wet FGD. Advanced Materials Research, 2013

2. H Pan, GZ Li.Properties Research and Mechanism Analysis of Polypropylene Fiber Reinforced FGD Gypsum Composites, Advanced Materials Research, 2013

3. JE Garlanger, TS Ingra. Evaluation of Chiyoda Thoroughbred 121 FGD process and gypsum stacking. Volume 3. Addendum.FOSSIL-FUELED POWER PLANTS, 1981 